\title{
Ancestral Caddo Fine Ware Vessels from Cahokian Sites in the Mid-Continent, ca. A.D. 1050-1300
}

Timothy K. Perttula

Heritage Research Center, Stephen F. Austin State University

Follow this and additional works at: https://scholarworks.sfasu.edu/ita

Part of the American Material Culture Commons, Archaeological Anthropology Commons, Environmental Studies Commons, Other American Studies Commons, Other Arts and Humanities Commons, Other History of Art, Architecture, and Archaeology Commons, and the United States History Commons

Tell us how this article helped you.

This Article is brought to you for free and open access by the Center for Regional Heritage Research at SFA ScholarWorks. It has been accepted for inclusion in Index of Texas Archaeology: Open Access Gray Literature from the Lone Star State by an authorized editor of SFA ScholarWorks. For more information, please contact cdsscholarworks@sfasu.edu. 
Ancestral Caddo Fine Ware Vessels from Cahokian Sites in the Mid-Continent, ca. A.D. $1050-1300$

\section{Creative Commons License}

\section{(c) (1) (8)}

This work is licensed under a Creative Commons Attribution-NonCommercial 4.0 International License 


\title{
Ancestral Caddo Fine Ware Vessels from Cahokian Sites in the Mid-Continent, ca. A.D. 1050-1300
}

\author{
Timothy K. Perttula
}

\section{Introduction}

Ancestral Caddo ceramic vessels and ceramic vessel sherds have been identified from Cahokia and other sites in the U.S. Midwest in contexts dating from ca. A.D. 1050-1300. Archaeological findings from recent work in the East St. Louis Precinct by the Illinois State Archaeological Survey provides a wealth of data on the Mississippian ceramics found there as well as ceramic wares of likely ancestral Caddo manufacture. These Caddo wares comprise less than 0.3 percent of the more than 15,600 vessel batches in the East St. Louis Precinct assemblage, and almost all of them are on local pastes. It is probable, therefore, that these ceramic vessels were made by Caddo potters that had emigrated to Cahokia and were living there.

\section{Ancestral Caddo Vessels from Cahokia and other U.S. Midwest Sites}

Engraved and finely incised ceramic vessels and ceramic vessel sherds with ancestral Caddo stylistic affiliations have been recovered from sites in the U.S. Midwest and the Cahokia region dating from ca. A.D. 1050-1300 for a number of years (see Anderson and Tiffany 1987; Bareis and Porter 1965; Kelly 1991; O'Brien 1972). The southern and northern Caddo areas are in the Trans-Mississippi South, more than $800 \mathrm{~km}$ to the southwest (Figure 1), centered on the Red River in Southwest Arkansas, Northwest Louisiana, Southeast Oklahoma, and East Texas (Perttula 2012:Figure 1-2).

Such fine wares identified in archaeological deposits in the Cahokia region include Crenshaw Fluted, Crockett Curvilinear Incised, Hickory Engraved, Holly Fine Engraved, and Spiro Engraved types (see Suhm and Jelks 1962; Durham and Davis 1975), types likely to have been manufactured in East Texas and in the Red River basin of the southern Caddo area (e.g., Lambert 2017). Their recovery and identification as ancestral Caddo vessels not local to the region (cf. Betzenhauser et al. 2018:293), as well as the recovery of items such as Missouri flint clay pipes and Long-Nosed God maskettes from ca. A.D. 1000-1200 contexts at the Gahagan site in Northwest Louisiana (see Emerson and Girard 2004; Girard et al. 2014:60 and Figure 2.3) has led to considerations of the relationships and connections that existed at the time between Cahokians and ancestral Caddo peoples.

More than 15,670 ceramic vessel batches were identified by Brennan et al. (2019; see also Betzenhauser et al. [2018]) from Lohmann (ca. A.D. 1050-1100), Stirling (ca. A.D. 1100-1200), and Moorehead (ca. A.D. 1200-1300) phase features and deposits in the East St. Louis Precinct investigations. Of these, 39 vessels ( 0.25 percent) have been identified on the basis of decoration, vessel form, and paste as having a "Caddo-inspired design and form" (Betzenhauser et al. 2018:298). While in no context are such vessels common, the highest proportion of these Caddo ceramics in the East St. Louis Precinct occur in Moorehead phase ( $\mathrm{n}=3,1.9$ percent) and Stirling phase ( $n=31$ vessels, 0.33 percent of the assemblage) deposits, with lesser amounts in Lohmann phase ( $n=5,0.11$ percent) contexts (Brennan et al. 2019). Where identifiable, vessel forms include 


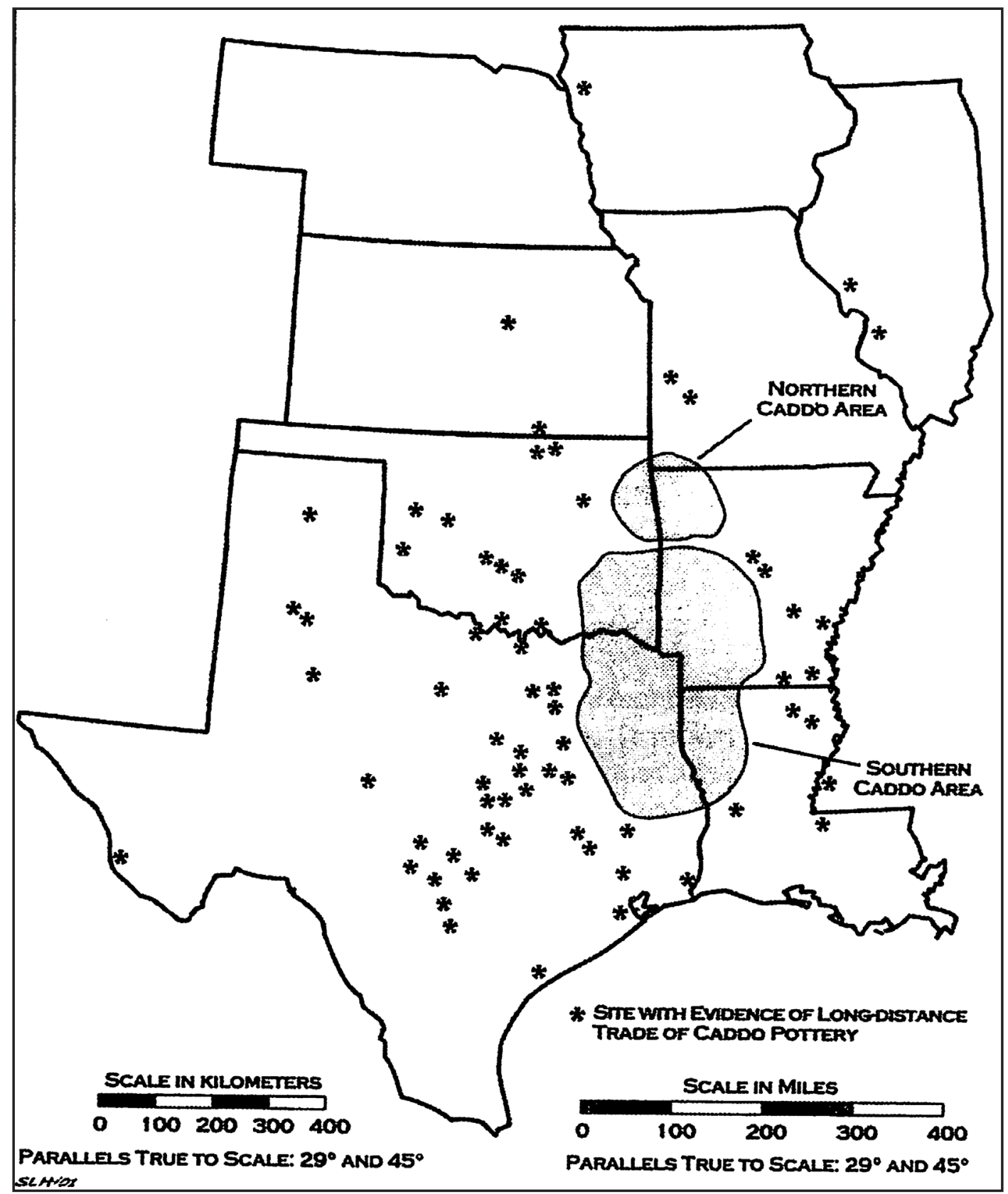

Figure 1. Distribution of Caddo ceramic wares that are the product of long-distance trade across sites in Texas, the Great Plains, and the Midwest, including Cahokia (from Perttula 2002:Figure 5.1).

carinated bowls $(n=2)$, an important Caddo vessel form, bowls $(n=15)$, beakers $(n=5)$, plates $(n=2)$, and jars $(n=2)$.

It is intriguing that these vessels with stylistically affiliated Caddo decorative elements and forms are almost always manufactured on local pastes with shell or shell-grog temper, rather than on a presumably non-local grog-tempered paste. Of these 39 vessels, 95 percent are made from local pastes, and only 5 percent are made from likely non-local pastes (Brennan et al. 2019). To account for this disparity, Brennan et al. (2019:446) suggest that it: 
is possible that some were transported as trade goods or as containers for goods, but based on the predominance of local clays, we contend that some of these vessels were most likely constructed in the American Bottom or surrounding region by peoples with knowledge of distant ceramic traditions, morphologies, and decorative designs (e.g., immigrants and imitators of their designs).

Based on strontium isotope analysis of teeth from contemporaneous burials in the East St. Louis Precinct, at least 10-20 percent of the individuals that lived at Cahokia were immigrants or "had been born to recent-immigrant mothers" (Nash et al. 2018:241; see also Hedman et al. 2018:209); exactly where these immigrants came from has yet to be established (Nash et al. 2018:242). However, in the case of the potters that made the ancestral Caddo ceramic vessels recovered at Cahokia and nearby sites, they likely came from the Red River basin and adjoining regions in the southern Caddo area, where such fine wares were made, after A.D. 1050.

Petrographic work (cf. Stoltman n.d) on these fine ware vessels, along with instrumental neutron activation analysis of the chemical composition of their paste (see Perttula 2002; Trubitt et al. 2016), is important to continue to do to establish their compositional nature and clarify whether they are locally or non-locally made. Their manufacturing locales need to be better pinpointed. Such analyses should be accompanied by stylistic, morphological, and technological consideration of the corpus of engraved and fine incised wares from Cahokian sites to: (a) establish their design grammar (cf. Early 2012; Lambert 2017) and vessel form construction methods (i.e., slab-constructed bottle necks are typical of Early Caddo period bottles), (b) compare these designs and forms to that of fine ware vessels made by potters living in southern Caddo area sites, and (c) assess the knowledge and skill retained by likely immigrant Caddo potters, or by local Cahokians imitating the designs and vessel forms brought into, or made at, Cahokia sites by Caddo immigrants.

\section{Acknowledgments}

I appreciate the cogent comments provided by Shawn Lambert on an earlier draft of the manuscript.

\section{References Cited}

Anderson, Duane C. and Joseph A. Tiffany

1987 A Caddoan Trade Vessel from Northwest Iowa. Plains Anthropologist 32(115):93-96.

Bareis, Charles J. and James W. Porter

1965 Megascopic and Petrographic Analyses of a Foreign Pottery Vessel from the Cahokia Site. American Antiquity 31(1):95-101.

Betzenhauser, Alleen, Tamira K. Brennan, Michael Brent Lansdell, Sarah E. Harken, and Victoria E. Potter

2018 Chronological Implications and External Connections in the East St. Louis Precinct Ceramic Assemblage. In Revealing Greater Cahokia, North America's First Native City: Rediscovery and Large-Scale Excavations of the East St. Louis Precinct, edited by Thomas E. Emerson, Brad H. Koldehoff, and Tamira K. Brennan, pp. 263-331. Studies in Archaeology No. 12. Illinois State Archaeological Survey, Prairie Research Institute, University of Illinois, Urbana-Champaign. 
Brennan, Tamira K., Michael Brent Lansdell, and Alleen Betzenhauser (editors)

2019 East St. Louis Precinct Mississippian Ceramics. Research Report No. 45. Illinois State Archaeological Survey, Prairie Research Institute, University of Illinois, UrbanaChampaign.

Durham, James H. and Michael K. Davis

1975 Report on Burials found at Crenshaw Mound "C," Miller County, Arkansas. Bulletin of the Oklahoma Anthropological Society 23:1-90.

Early, Ann M.

2012 Form and Structure in Prehistoric Caddo Pottery Design. In The Archaeology of the Caddo, edited by Timothy K. Perttula and Chester P. Walker, pp. 26-46. University of Nebraska Press, Lincoln.

Emerson, Thomas E. and Jeffrey S. Girard

2004 Dating Gahagan and Its Implications for Understanding Cahokia-Caddo Interactions. Southeastern Archaeology 23(1):57-64.

Girard, Jeffrey S., Timothy K. Perttula, and Mary Beth Trubitt

2014 Caddo Connections: Cultural Interactions within and beyond the Caddo World. Rowman \& Littlefield, Lanham, Maryland.

Hedman, Kristin M., Philip A. Slater, Matthew A. Fort, Thomas E. Emerson, and John M. Lambert

2018 Expanding the strontium isoscape for the American midcontinent: Identifying potential places of origin for Cahokian and Pre-Columbian migrants. Journal of Archaeological Science: Reports 22:202-213.

Kelly, John E.

1991 The Evidence for Prehistoric Exchange and Its Implications for the Development of Cahokia. In New Perspectives on Cahokia, Views from the Periphery, edited by James B. Stoltman, pp. 65-92. Monographs in World Archaeology No. 2. Prehistory Press, Madison, Wisconsin.

Lambert, Shawn P.

2017 A Stylistic and INAA Study of Formative Caddo Fine Wares: Evidence for Centralized Production and Long-Distance Exchange between the Northern and Southern Caddo. Ph.D. dissertation, Department of Anthropology, University of Oklahoma, Norman.

Nash, Lenna, Kristin M. Hedman, and Matthew A. Fort

2018 The People of East St. Louis. In Revealing Greater Cahokia, North America's First Native City: Rediscovery and Large-Scale Excavations of the East St. Louis Precinct, edited by Thomas E. Emerson, Brad H. Koldehoff, and Tamira K. Brennan, pp. 219-262. Studies in Archaeology No. 12. Illinois State Archaeological Survey, Prairie Research Institute, University of Illinois, Urbana-Champaign.

O’Brien, Patricia J.

1972 A Formal Analysis of Cahokia Ceramics from the Powell Tract. Monograph No. 3. Illinois Archaeological Survey, Urbana. 
Perttula, Timothy K.

2002 Archaeological Evidence for the Long-Distance Exchange of Caddo Indian Ceramics in the Southern Plains, Midwest, and Southeastern United States. In Geochemical Evidence for Long-Distance Exchange, edited by Michael D. Glascock, pp. 89-107. Bergin and Garvey, Westport, Connecticut.

2012 The Archaeology of the Caddo in Southwest Arkansas, Northwest Louisiana, Eastern Oklahoma, and East Texas: An Introduction to the Volume. In The Archaeology of the Caddo, edited by Timothy K. Perttula and Chester P. Walker, pp. 1-25. University of Nebraska Press, Lincoln.

Stoltman, James B.

n.d. Petrographic Observations on the "Caddoan" Vessel from the Siouxland Sand and Gravel Site. MS on file with the author.

Suhm, Dee Ann and Edward B. Jelks (editors)

1962 Handbook of Texas Archeology: Type Descriptions. Special Publication No. 1, Texas Archeological Society, and Bulletin No. 4, Texas Memorial Museum, Austin.

Trubitt, Mary Beth, Timothy K. Perttula, and Robert Z. Selden, Jr.

2016 Identifying Ceramic Exchange and Interaction between Cahokia and the Caddo Area. In Research, Preservation, Communication: Honoring Thomas J. Green on His Retirement from the Arkansas Archeological Survey, edited by Mary Beth Trubitt, pp. 87-102. Research Series No. 67. Arkansas Archeological Survey, Fayetteville. 